\title{
Expression of MRP8/MRP14 mRNA in Monocytes of Periodontitis : Comparison between Diabetic and Non Diabetic Patients
}

\author{
Ahmad Syaify ${ }^{1}$ \\ Sri Budi Barunawati ${ }^{2}$ \\ Suryono ${ }^{1}$ \\ Marsetyawan HNES ${ }^{3}$
${ }^{1}$ Departement of Periodontology, Faculty of Dentistry, Universitas Gadjah Mada, Yogyakarta, Indonesia
${ }^{2}$ Departement of Prosthodontic, Faculty of Dentistry, Universitas Gadjah Mada, Yogyakarta, Indonesia
${ }^{3}$ The Profesor of Immunology at Faculty of Medicine, Universitas Gadjah Mada, Yogyakarta, Indonesia \\ E-mail:ahmad_syaify@yahoo.com \\ Received September 15, 2010 ; Accepted October 15, 2010
}

\begin{abstract}
The severity of periodontitis on patients with type 2 Diabetes Mellitus patients was strongly thought caused by decreasing of leukocytes function such as monoctyes and neutrophils. In our previous research it was found that calprotectin (MRP8/MRP14) level in leukocytes of periodontitis patients with type 2 DM was higher than periodontitis in non DM. The aim of this study was to determine calprotectin (MRP8/MRP14) mRNA expression in human monocytes of periodontitis patients with type $2 \mathrm{DM}$ and without DM. Monocytes were isolated from the peripheral blood of periodontitis patients with uncontrolled type $2 \mathrm{DM}$, controlled type 2 DM, and non DM. The expression of total RNA calprotectin (MRP8 and MRP14) were detected by RTPCR using GAPDH as the innate control. It was observed that the value of MRP8/MRP14 mRNA expression DM patients were higher than non DM, and the highly significant increase expression $(p<0.05)$ was on the uncontrolled type 2 DM. The basal level of MRP8/MRP14 expression increased in monocyte of periodontitis and type 2 DM patients compared with non diabetes subjects. It was suggested that high basal level MRP8/ MRP14 has role in the regulation of severity periodontitis with diabetes mellitus.
\end{abstract}

Keywords: MRP8/MRP14, monocytes, periodontitis, type 2 DM.

\section{Introduction}

Diabetes mellitus is a common and growing global health problem. It is highly prevalent in Asian populations and about 90 percent of diabetes mellitus is type 2 (Non Insulin Dependent Diabetes Mellitus/NIDDM). In Indonesia, the incidence rate for those who are above 15 years old in Indonesia was $1,2-2,3 \%$ and it has tendency to increase. ${ }^{1}$ Among the late complications assosiated to the diabetes mellitus, periodontitis has been highlighted, and it can be more severe and refractory to treatment than in healthy subjects. ${ }^{2}$ Meanwhile, periodontitis is still a problem in the field of dentistry and ranked number-eight of the 10 major outpatients diseases at the General Hospital in Indonesia ${ }^{3}$

The incidence of periodontitis increases, more frequent and severe in diabetic patients with more advanced systemic complications, and the increased susceptability does not correlate with increased 
levels of dental plaque or calculus. ${ }^{4}$ The severity of periodotitis in diabetic patient was strongly thought caused by decreasing of leukocytes function such as monocytes and neutrophils. As one of very frequent complication of diabetes mellitus, periodontitis was known to be caused by immune response disturbances such as; decreasing of chemotaxis, adherence, and phagocytosis of neutrophils. ${ }^{5}$

Calprotectin is a calcium binding protein that has a molecular weight of $36.5 \mathrm{kDa}$, belongs to the S100 protein family and its detected in monocytes, neutrophils, and epithelial cells, being composed of two subunits macrophage migration inhibitory factor-related protectin 8 and 14 (MRP8 and MRP14). ${ }^{6.7}$ It is known that calprotectin plays an important role in the innate immunitiy, and its level is markedly increase in plasma, feces, and synovial fluid from patients with infections and inflamatory diseases ${ }^{8}$. Calprotectin level in gingival crevicular fluid (GCF) of periodontitis patients was significanly higher than healthy subjects and it was detected in gingival tissue only from the periodontitis patients. ${ }^{1,2}$

It was also known that calprotectin has the extracellular function, including antibacterial, chemotactic factor, and inhibition binding of pathogenic bacteria to the epithelial cell, suggest that calprotectin may play a role in the immune response mechanism of periodontitis ${ }^{9}$. However, the exact role of calprotectin in periodontitis patient with diabetes mellitus is unclear. In our previous research, it was found that the calprotectin level in serum of periodontitis patients with type 2 diabetes mellitus is higher than periodontitis of non DM patients ${ }^{10}$, and the basal level of calprotectin mRNA MRP8/MRP14 expression increased in neutrophils of periodontitis patients with type 2 diabetes mellitus. ${ }^{11}$

In the present study, we determine calprotectin mRNA (MRP8/MRP14) expression in human mon ocytes of periodontitis patients with type 2 diabetes mellitus, comparing between diabetic and non diabetic mRNA. The aim of this study was to determine calprotectin expression in human neutrophils of periodontitis patients with type 2 diabetes mellitus, both controlled and uncontrolled hyperglycemic, compare with non diabetic subject.

\section{Materials and Methods}

\subsection{Monocytes preparation and isolation}

First peripheral blood was collected from 36 periodontitis subjects with and without type 2 diabetes mellitus following informed consent to participate in the study. The diabetic subjects were outpatients who came to the Dr. Sardjito General Hospital Yogyakarta, whereas periodonitis and non diabetic patients were obtained from the Dental Hospital of the Faculty of Dentistry, Gadjah Mada University, Yogyakarta. Monocytes were separated from heparinized blood by density gradient centrifugation using Histopaque ${ }^{\circledR}-1077$ (SigmaAldrich), and these cells were collected in eppendorf tube as samples for RNA determination.

Monocytes from periodontitis subjects with unconrolled DM, controlled DM, and non DM were isolated from its RNA using Trizol $^{\circledR}$ Reagent (Invitrogen) according to the manufacturer's protocol. Into pellet cell $1 \mathrm{ml}$ Trizol Reagent was added, suspensed with injection spuit and incubated in room temperature for 5 minutes. Chloroform was added $20 \mu \mathrm{l}$ and mixed by hands, then centrifugated $12.000 \mathrm{~g}$ for 15 minutes in temperature $4^{\circ} \mathrm{C}$. Aqueous phase was transferred by mixing with fresh tube and the RNA was precipitated from the aqueous phase by mixing with $500 \mu \mathrm{l}$ isoprophyl alcohol. RNA samples were incubated at room temperature for 10 minutes and then centrifuged at $12.000 \times \mathrm{g}$ for 10 minutes at $4^{\circ} \mathrm{C}$. The RNA pellet was washed with 1 $\mathrm{ml}$ ethanol $75 \%$ and mixed the sample by vortexing and centrifugation at $7.500 \times \mathrm{g}$ for 5 minutes at $4^{\circ} \mathrm{C}$. The RNA pellet was briefly dried with vacuum dry for 3 minutes and redisolving the RNA in $30 \mu$ RNAse free water.

\subsection{Determination RNA calprotectin by RT-PCR.}

Calprotectin RNA (MRP8 and MRP14) expression was determined by Reverse Transcriptase Polymerase Chain Reaction (RT-PCR) according to manufacturer's procedure. Two steps RT-PCR procedures were used, 
first step was CDNA syntesis from RNA samples and continued with PCR procedure as the second step. Master mix for cDNA synthesis was: $10 \times$ Reaction Buffer, $25 \mathrm{mM} \mathrm{MgCl}$, Deoxy Nucleotid Mix, Primer pd $(T)_{6}$, RNAse Inhibitor, and AMV RT. To determine mRNA calprotectin, we amplified cDNA samples and PCR Primers for Calprotectin (Table 1 ) by polymerase chain reaction (PCR). PCR products were then checked by electrophoresis to measured band intesity of the MRP8 and MRP14 Calprotectin mRNA. The intensity of each band was normally done by comparing it with the GAPDH band. The expression of calprotectin (MRP18 and MRP14) mRNA was represented as the intensitiy of bands that were checked by thin layer chromatography (TLC) and represented as mean relative total RNA \pm SD from the samples.

Table 1. PCR Primers in this study

\begin{tabular}{lll}
\hline Oligonucleotide & Sequence & Product \\
\hline MRP8 sense & 5:-GCTGGAGAAAGCCTTGAACTC-3' & 232 bp \\
MRP8 antisense & 5 -CCACGCCCATCTTrATCACCA-3' & \\
MRP 14 sense & 5'-TCGCAGCTGGAACGCAACATA-3' & 213 bp \\
MRP14 antisense & 5'-AGCTCAGCTGC TTGTCTGCAT-3' & \\
GADPH sense & 5'-TCCACACC CTGTTGCTGTA-3' & 558 bp \\
GAPDH antisense & 5'-ACCACAGTCCATGCCATCAC-3' & \\
\hline
\end{tabular}

\subsection{Statistical analysis}

Statistical analysis was performed by One Way ANOVA for the samples. Values of $p<0.05$ were accepted as statistically significant. Results were expressed as the mean $\pm S D$ and statistical analysis.

\section{Results}

The band position of calprotectin mRNA (MRP8 and MRP14) and also GAPDH were in correct position based on the base pairs (bp) values of GAPDH (558 bp), MRP8 (232 bp), and MRP14 (213 bp) as mentioned by the manufacturer's protocol. The suitable position of all oligonucelotides compared with the $100 \mathrm{bp}$ DNA ladder were shown on Figure 1.

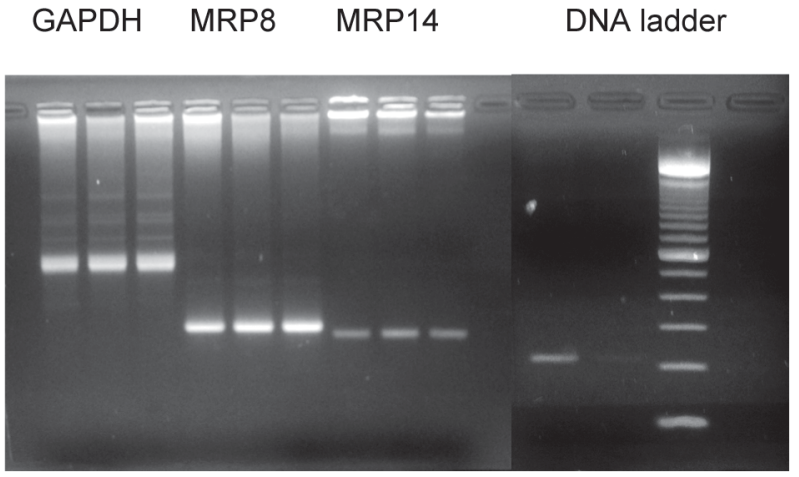

Figure 1. Band position of MRP8, MRP14, GAPDH primers comparing with $100 \mathrm{bp}$ DNA ladder. All primers were in the correct positions base on the values of base pairs (bp).

To determine the influence of hyperglycemic condition on diabetic subjects to MRP8 and MRP14 expression in human monocytes of periodontitis patients, the expression of MRP8/14 mRNA was examined. When monocytes were isolated from diabetic and non diabetic subjects, the expression of MRP8 mRNA was significantly higher than MRP14 mRNA. The intensity of bands markedly increased in uncontrolled DM patient (Fig.2).

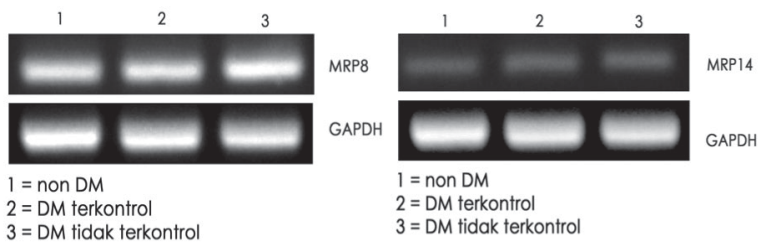

Figure 2. MRP8/MRP14 mRNA expression of human monocytes from diabetic and non diabetic subjects. The expression of mRNA was determined in 1mg RNA from resting neutrophils by RT-PCR using MRP8, MRP14, and GAPDH primers.

Both MRP8 and MPR14 mRNA expression in periodontitis patients with type $2 \mathrm{DM}$ were higher than non DM patients, while the highest expression of mRNA MRP8/MRP14 was in uncontrolled DM (Table 2); suggesting that MRP8/MRP14 mRNA has importance role for severity of periodontitis in diabetic patient. The result of One Way ANOVA (Table 3) showed that the expression of MRP8 and MRP 14 in human monocytes of periodontitis patients were significantly influenced by diabtetics status $(p<0.05)$. The LSD test showed significant difference of the 
means of non diabetic and uncontrolled diabetic, controlled and uncontrolled diabetic, whereas the means of non diabetic and controlled diabetic were not significantly different (Table 4).

Table 2. Mean and standard deviation of expression of monocyte MRP8/MRP14 non-diabetic patients with periodontitis, periodontitis with controlled DM and uncontrolled DM.

\begin{tabular}{llll}
\hline Group & $\begin{array}{l}\text { Number of } \\
\text { sampel }\end{array}$ & \multicolumn{2}{c}{ Mean \pm SD } \\
& & MRP8 & MRP14 \\
\hline $\begin{array}{l}\text { Periodontitis non } \\
\text { diabetic }\end{array}$ & 12 & $0.939 \pm 0.385$ & $0234 \pm 0.149$ \\
$\begin{array}{l}\text { Periodontitis } \\
\text { controlled diabetic }\end{array}$ & 12 & $1.154 \pm 0.461$ & $0.278 \pm 0.172$ \\
$\begin{array}{l}\text { Periodontitis } \\
\text { uncontrolled diabetic }\end{array}$ & 12 & $1.579 \pm 0.774$ & $0.549 \pm 0.469$ \\
\hline
\end{tabular}

Table 3. Oneway ANOVA results on the expression of calprotectin MRP8/MRP14 in monocytes of periodontitis non-diabetic patients, periodontitis with controlled DM and periodontitis with uncontrolled DM.

\begin{tabular}{|c|c|c|c|c|c|}
\hline & \multicolumn{5}{|c|}{ Expression of MRP8 RNA monocytes } \\
\hline & $\begin{array}{l}\text { Sum of } \\
\text { squares }\end{array}$ & Df & $\begin{array}{l}\text { Means } \\
\text { square }\end{array}$ & $\mathbf{F}$ & $\mathbf{p}$ \\
\hline Between groups & 2.547 & 2 & 1.274 & 3.972 & $0.028 *$ \\
\hline Within groups & 10.581 & 33 & 0.321 & & \\
\hline \multirow[t]{2}{*}{ Total } & 13.129 & 35 & & & \\
\hline & \multicolumn{5}{|c|}{ Expression of MRP8 RNA monocytes } \\
\hline Between groups & 0.696 & 2 & 0.348 & 3.890 & $0.030 *$ \\
\hline Within groups & 2.951 & 33 & 0.089 & & \\
\hline Total & 3.647 & 35 & & & \\
\hline
\end{tabular}

Table 4. Statistical results of LSD test from MRP8/ MRP14 expression on monocytes periodontitis non-diabetic patients, periodontitis with controlled DM, and periodontits with uncontrolled DM.

\begin{tabular}{lll}
\hline \multirow{2}{*}{ Groups } & \multicolumn{2}{c}{$\mathbf{P}$} \\
\cline { 2 - 3 } & MRP8 & MRP14 \\
\hline Non DM-controlled DM & 0.359 & 0.721 \\
Non DM-uncontrolled DM & $0.009^{* *}$ & $0.015^{*}$ \\
Controlled DM-uncontrolled DM & 0.075 & $0.034^{*}$ \\
\hline
\end{tabular}

42

\section{Discussion}

Periodontitis is always found among diabetic patients, and severity of periodontitis on diabetic is more progressive than non diabetic patients although the bacteria that caused were the same. ${ }^{12.13}$ Some studies show that increasing severity of diabetic periodontitis is mainly influenced by the immune system disorders. ${ }^{14.15}$ The existence of vascular changes in the form of capillary basal membrane thickening due hyperglicemic conditions, also causes disruption of the nutrients and the migration of immune cells into the periodontal tissue. ${ }^{12}$ Calprotectin (MRP8/MRP14) is cytosolic protein that has important functions as chemotactic factor associated with the activation of monocytes and neutrophils, and accumulation of cells of innate immunity in areas of inflammation as well as an antibacterial protein. It also has adhesion, regulation, migration activities of monocytes and neutrophils, and is recently known to have important role in body immunity an a natural immune system of periodontal tissues. ${ }^{9.22}$

This study identified that calprotectin mRNA (MRP8/MRP14) expression in monocytes of periodontitis with type 2 diabetes mellitus was different from periodontitis in non diabetes patients, and the highest calprotectin expression was on uncontrolled type 2 diabetes mellitus compared with controlled diabetes and non diabetes (Table 2). The different expressions of calprotectin from human monocytes on diabetic and non diabetic patients strongly suspect correlation with impairment of immune cell function, especially innate immunity cells such as monocytes and neutrophils. Some authors mentioned that this impairment of function including chemotaxis, diapedesis, and phagocytosis of neutrophils, ${ }^{17}$ but which one of those functions that was very dominant to cause severity of diabetic periodontitis remains unclear. Our result showed that calprotectin MRP8/MRP14 mRNA expression in periodontitis patients with diabetes mellitus was different with non diabetic subjects, while calprotectin has been well known as a chemotactic factor. ${ }^{18.19}$ The previous study demonstrated that diabetics patients with severe periodontitis depressed PMN (neutrophils) chemotaxis compared 
to those with periodontitis on non diabetic subjects with severe or mild periodontitis. ${ }^{4}$

The results of the study also identified that the highest calprotectin MRP8/14 mRNA expression were in periodontitis patients with uncontrolled type 2 diabetes mellitus. It may be caused by proinflammatory cytokines that markedly increased in blood of uncontrolled diabetes mellitus patient. Proinflammatory cytokines such as TNF-alfa and IL1-beta were present in large amount in blood circulating diabetic patients, and it was reported that its level is higher in uncontrolled DM than controlled DM. ${ }^{20.21}$ These cytokines, both TNF-alfa and IL-1beta, are found in the circulating peripheral blood and its level is increased in several inflammatory diseases, including periodontitis. In the previous study, it was reported that expression of MRP8/MRP14 was increased in monocytes by several factors and compounds including TNF-alfa, and it was also known that this cytokine can stimulate calprotectin expression in human monocytes and neutrophils. 22.23

MRP8/MRP14 is found predominantly in a cytosolic location in both monocytes and neutrophils, it represents about $45-60 \%$ of the total neutrophils cytosolic protein. ${ }^{6.24}$ After activations of neutrophils, MRP8 and MRP14 are released into the extracellueler compartment via tubulin dependent pathway, where they are known to promote the adhesion of neutrophlis and monocytes to endothelium. ${ }^{24}$ Previously, we identified high basal level concentration of calprotectin intracellular in monocyte and neutrophils that was determined by ELISA kit (unpublished data). We also found the increasing basal level of calprotectin in serum of periodontitis patients with type 2 diabetes mellitus. ${ }^{10}$ In this study, we found the same pattern of increasing calprotectin mRNA expression in uncontrolled type 2 diabetic patients. It can be understood, because uncontrolled diabetic patients have persistently high concentration of TNF-alfa in their blood circulation, whereas TNF-alfa potentially stimulates monocytes to increase MRP8/MRP14 mRNA expression and calprotectin production.

Our conclusion is the basal level of calprotectin mRNA MRP8/MRP14 expression increased in monocytes of periodontitis patient with type $2 \mathrm{DM}$ compared with non diabetes subjects. It was suggested that high basal level of calprotectin mRNA has role in the regulation of severity of periodontitis with diabetes mellitus. Therefore, MRP8/MRP14 may be a potentially selective novel biomarker for early symptom of diabetic periodontitis.

\section{Acknowledgment}

The authors are very grateful to Lembaga Ejikman Jakarta and Graduate Program at the Facuty of Dentistry, Gadjah Mada University, Yogyakarta for giving authors opportunity to conduct research. This study was supported by grant from Research and Development of The Ministry of Health of the Republic of Indonesia (Litbang Depkes RI).

\section{References}

1. Perkeni. 2001. Konsensus Pengelolaan Diabetes Mellitus Tipe 2 di Indonesia. Jakarta: 142.

2. Arrieate-Blanco JJ, Bartolome-Villar B, JimenezMartinez E, Saavedra-Vallejo P. 2003. Dental problems in patients with DM (II): ginginal index and perodontal disease. Med Oral. 8: 233-47.

3. Depkes RI. 2002. Profil Kesehatan Indonesia 2001: Menuju Indonesia Sehat 2010. Pusat Data Departemen Kesehatan RI, Jakarta.

4. Mealey B. 2000. Diabetes and periodontal disease: Position Paper. J. Periodontol. 70: 93549.

5. Iacopino AM, and Cuttler CW. 2000. Pathophysiological relationship between periodontitis and systemic disease: recent concept involving serum lipids in periodontitis and systemic disease. J. Periodontol, 71 (8): 137584.

6. Fagerhol MK, Andersson KB, Naess-Andresen $\mathrm{C}$, Brandzaeg C, Dale I. 1990. Calprotectin (The L1 Leukocyte Protein) in Smith, V.L., Dedman J.R, eds. Stimulus Response Coupling: The Role of Intercellular Calcium-binding Proteins. Boca Raon, CRC Press: 187-210.

7. Kerkhoff C, Klempt M, Sorg C. Novel insights into Structure and Function of MPR8 (S199A8) and MPR14 (S100A9). Biochem Biophsy Acta 1448: 200-11.

8. Fagerhol MK. 2000. Calportectin, a faecal marker of organic gastrointestinal abnormality. Lancet 356: 1783-4. 
9. Suryono, Kido J, Hayashi N, Kataoka M, Nagata T. Calprotectin Expresssion in Human Monocytes: Induction by Porphyromonas gingivalis Lipopolysaccharide, Tumor Necrosis Factor- $\alpha$, and Interleukine-1ß. J. Periodontol. 76 : 437-42.

10. Ahmad Syaify, Marsetyawan, Suryono. Level of Calprotectin ini Serum of Periodontitis Patient with Type 2 Diabetes Mellitus. 2008. Journal of PDGI, Special edition in Congress XXII March 2008: 1-5.

11. Ahmad Syaify, Marsetyawan, Sudibyo, Suryono. 2008. Calprotectin mRNA (MRP8/MRP14) expression in neutrophils of periodontitis patients with type 2 diabetes mellitus. Dental Journal 42 (3): 130-3.

12. Ryan EM, Carnu O, Kamer A. 2003. The Influence of Diabetes on the Periodontal Tissues. J. Am. Dent. Ass 143: 34S - 40S.

13. Southerland JH, Taylor GW, Offenbacher S. 2005. Diabetes and Periodontal Infection Making the Connection. Clinical Diabetes. 23 (4): 171-8.

14. Miller LS, Manwell MA, Newbold D. 1992. The Relationship between reduction in Periodontal Inflammation and Diabetes Control: a Report of 9 Cases. J. Periodontol 63 (10): 843-8.

15. Grossi SG, and Genco RJ. 1998. Periodontal Disease and Diabetes Mellitus: a Two-way Relationships. Annal of Periodontol 3(1): 51 -61.

16. Suryono, Kido J, Hayashi N, Kataoka M, Shinohara Y, Nagata I. 2006. Noreohineohrin stimulates calprotetcin expression in human monocytes cell. J Periodont Res 41: 159-64.

17. Little JW, and Falace DA.1988. Dental Management of The Medically Compromised Patient. $3^{\text {rd }}$ Ed. Mosby Co., St. Louis: 291-307.
18. Hessian PA, Edgeworth J, Hogg N. 1993. MRP-8 and MRP-14, two abundant $\mathrm{Ca}$-binding proteins of neutrophil and monocytes. J. Leukocyte Biol. 53: 197-203.

19. Miyasaki KT, Bodeua AM, Shafer WM, Pohl J, Murthy RK, Lehrer RI. 1994. New ideas about neutrophil antimicrobial mechanisme: antibiotic peptides, postphagocytic protein processing, and cytosolic defense factors, in Molecular Pathogenesis of Periodontal Disease. American Society for Microbiol, Washington D.C.: 321-35.

20. Marhamah. 2004. Pathomechanism of periodontal tissue damage in patients with type 2 diaebets mellitus. Disertation. Hasanuddin University, Makasar, Indonesia.

21. Graves DT, Liu R, Alikhani M, Al-Mashat H, Trackman PC. 2006. Diabetes-anhanced inflammation and apoptosis: impact on periodontal pathology. J.Dent Res. 85(1): 15-21.

22. Suryono, Kido J, Hayashi N, Kataoka M, Nagata T. 2003. Effect of Porphyromonas gingivalis lipopolysaccharide, tumor necrosis factor-alfa and interleukin 1-beta on calprotectin release in human monocytes. J Periodontol 74: 1719-24.

23. Kido J, Kido R, Suryono, Kataoka M, Fagerhol MK, Nagata T. 2003. Calprotectin release from human neutrophils is induced by Porphyromonas gingivalis lipopolysaccharide via the CD-14-Toll like receptor-NFKB pathway. J Periodontol Res 38: 557-63.

24. Ehlermann $P$, Eggers $K$, Bierhaus $A$, Most $P$, Weuchenhan D, Greten J, Nawroth PP, Katus HA, Remppis A. 2006. Increased proinflamatory endothelial respons to S100A8/9 after preactivation through advanced glycation end products. Cardiovascular Diabetology 5(6): 1-9. 